\title{
POLA SPASIAL DAMPAK DISPERSI GAS NITROGEN DIOKSIDA KABUPATEN SERANG PROVINSI BANTEN
}

\section{SPATIAL PATTERNS OF NITROGREN DIOXIDE GAS DISPERSION IMPACT IN SERANG REGENCY BANTEN PROVINCE}

\author{
Ahmad Pratama Putra ${ }^{1}$ \\ ${ }^{1}$ Pusat Teknologi Reduksi Risiko Bencana (PTRRB) - BPPT, Gedung 820 \\ GEOSTECH, PUSPIPTEK, Kota Tangerang Selatan, telepon: (021) 75791378 \\ e-mail: ahmad.pratama@bppt.go.id
}

\begin{abstract}
The main activities in Serang Regency which are suspected to produce pollutants and air emissions include industrial business activities where the pollutants produced are in the form of Nitrogen Dioxide $\left(\mathrm{NO}_{2}\right)$ gas which is not only dangerous for humans and animals, but also dangerous for plant life. Therefore, this study tries to examine the spatial pattern of $\mathrm{NO}_{2}$ gas dispersion and its impact on settlements in Serang Regency. Based on the results of ambient air quality measurements in Serang Regency, which have been measured by the Serang Regency Environmental Agency from 2015 - 2019 for the $\mathrm{NO}_{2}$ parameter, it is seen that none of them exceed the standard of the PP No. 41 of 1999 concerning Air Pollution Control. The results of gas dispersion modeling show a tendency that gas concentration is relatively high in industrial zones, which indicates the contribution of gases from industrial business activities in several monsoons. The most extensive settlement affected by $\mathrm{NO}_{2}$ gas with the highest value $\left(40-50 \mu \mathrm{g} / \mathrm{Nm}^{3}\right)$ is in Cikande District covering an area of $396.4 \mathrm{Ha}$ which occurs during the west monsoon (December-February).
\end{abstract}

Keywords: spatial patterns, nitrogen dioxide dispersion, Serang District

\begin{abstract}
ABSTRAK
Berbagai kegiatan utama di Kabupaten Serang yang diduga dapat menghasilkan polutan dan emisi udara antara lain adalah dari kegiatan usaha industri dimana polutan yang dihasilkan antara lain berupa gas Nitrogen Dioksida $\left(\mathrm{NO}_{2}\right)$ yang tidak hanya berbahaya untuk manusia dan hewan saja, tetapi juga berbahaya bagi kehidupan tanaman. Oleh karena itu, kajian ini mencoba menelaah pola spasial dispersi gas $\mathrm{NO}_{2}$ dan dampaknya terhadap permukiman di Kabupaten Serang. Berdasarkan hasil pengukuran kualitas udara ambien di Kabupaten Serang yang telah diukur oleh Dinas Lingkungan Hidup Kabupaten Serang dari tahun 2015 - 2019 untuk parameter $\mathrm{NO}_{2}$, terlihat bahwa tidak ada satupun yang melampaui baku mutu PP No. 41 Tahun 1999 tentang Pengendalian Pencemaran Udara. Hasil pemodelan dispersi gas menunjukkan adanya suatu kecenderungan bahwa konsetrasi gas relatif tinggi pada zona-zona industri, yang menunjukkan adanya kontribusi gas-gas dari kegiatan usaha industri pada beberapa angin musim. Permukiman paling luas yang terdampak oleh gas $\mathrm{NO}_{2}$ dengan nilai paling tinggi $\left(40-50 \mu \mathrm{g} / \mathrm{Nm}^{3}\right)$ berada pada Kecamatan Cikande seluas 396,4 $\mathrm{Ha}$ yang terjadi pada saat angin musim barat (Desember-Februari).
\end{abstract}

Kata kunci: pola spasial, dispersi nitrogen dioksida, Kabupaten Serang 


\section{PENDAHULUAN}

\section{$1.1 \quad$ Latar Belakang}

Pencemaran udara, khususnya di kota-kota besar, sudah merupakan masalah yang perlu segera ditanggulangi. Hal ini akibat dari peningkatan aktivitas manusia, pertambahan jumlah penduduk, perkembangan ilmu pengetahuan dan teknologi, serta pertambahan industri dan sarana transportasi (KLH, 2004). Pencemaran udara ini dari waktu ke waktu diperkirakan akan semakin meningkat seiring dengan laju pertumbuhan pembangunan di berbagai sektor seperti sektor industri, perhubungan/transportasi dan pariwisata. Demikian juga halnya yang terjadi di Kabupaten Serang, dimana permasalahan terkait polusi udara yang terjadi terkait erat dengan sumber-sumber utama penyebab pencemaran udara seperti industri dan transportasi. Perkembangan yang pesat dari kegiatan-kegiatan utama tersebut secara nyata akan memberikan dampak terhadap meningkatnya kondisi polusi udara.

Berbagai kegiatan utama di Kabupaten Serang yang diduga dapat menghasilkan polutan dan emisi udara antara lain adalah dari kegiatan usaha industri dimana polutan yang dihasilkan antara lain asap, debu, grit (pasir halus), dan gas-gas. Selain itu, dari proses peleburan pada proses industri, misalnya pada industri peleburan baja, pembuatan soda, semen, keramik, aspal, dengan polutan yang dihasilkannya meliputi debu, uap, dan gas.

Industri merupakan salah satu sumber pencemaran udara, baik di perkotaan maupun di pedesaan. Emisi pencemar udara terutama berasal dari pembakaran bahan bakar di berbagai kegiatan industri termasuk pembangkit tenaga listrik, produksi kimia, dan lainnya, pengolahan logam, insenerasi, penggunaan bahan bakar industri, dan lain-lain (Muhammad dan Nurbianto, 2006).

Kegiatan industri menghasilkan emisi yang sangat tinggi yang dikeluarkan melalui cerobong. Dengan semakin banyaknya jenis kegiatan industri maka emisi yang dihasilkan akan semakin besar, terutama untuk kegiatan industri yang menghasilkan bahan berbahaya dan beracun (KLH, 2008).

Begitupun dengan pembangkit listrik, walaupun pembangkit listrik telah mempunyai alat pembersih endapan (precipirator) untuk membersihkan partikel-partikel kecil dari asap pembakaran batubara, namun senyawa-senyawa seperti SOx, NOx, dan partikel debu (PM10) yang berbentuk gas dengan bebasnya naik melewati cerobong dan terlepas ke udara bebas (Witono, 2003). Gas SOx dan NOx dapat bereaksi dengan uap air yang ada di udara membentuk asam sulfat $\left(\mathrm{H}_{2} \mathrm{SO}_{4}\right)$ dan asam nitrat $\left(\mathrm{HNO}_{3}\right)$. Kedua asam tersebut dapat jatuh bersama-sama air hujan sehingga mengakibatkan hujan asam yang dapat merusak lingkungan dan mengganggu kesehatan.

Udara yang telah tercemar oleh gas nitrogen dioksida $\left(\mathrm{NO}_{2}\right)$ tidak hanya berbahaya untuk manusia dan hewan saja, tetapi juga berbahaya bagi kehidupan tanaman. Hal ini disebabkan oleh kelarutan $\mathrm{NO}_{2}$ dalam air lebih rendah bila dibanding $\mathrm{SO}_{2}$, maka $\mathrm{NO}_{2}$ akan menembus ke dalam saluran pernapasan lebih dalam. Bagian saluran yang pertama kali dipengaruhi adalah membrane mukosa dan jaringan paru (KLH, 2009).

Pencemaran udara oleh gas NOx juga dapat menyebabkan timbulnya peroxy acetil nitrates yang disingkat PAN. PAN ini menyebabkan iritasi pada mata yang menyebabkan mata terasa pedih dan berair. Campuran PAN bersama senyawa kimia lainnya yang ada di udara dapat menyebabkan kabut foto kimia atau photo chemistry yang sangat mengganggu lingkungan ( $\mathrm{KLH}, 2009)$.

Udara dapat digolongkan menjadi dua yaitu udara emisi atau udara yang keluar dari sumber pencemar dan udara ambien. Hasil-hasil pemantauan kualitas udara ambien terutama parameter gas $\mathrm{NO}_{2}$ yang telah dilakukan di Kabupaten Serang memerlukan kajian pola spasial dispersinya agar dapat dilihat persebaran dampaknya. Oleh karena itu, kajian spasial dispersi gas $\mathrm{NO}_{2}$ dan dampaknya terhadap permukiman dilakukan pada studi ini.

\section{METODOLOGI}

\section{$2.1 \quad$ Lokasi}

Lokasi kajian ini adalah di daerah Kabupaten Serang. Kabupaten Serang terletak antara $5^{\circ} 50^{\prime}$ sampai $6^{\circ} 21^{\prime}$ Lintang Selatan dan $105^{\circ} 0^{\prime}$ sampai $106^{\circ} 22^{\prime}$ Bujur Timur. Kabupaten Serang memiliki luas wilayah $1.467,35 \mathrm{~km}^{2}$. Kabupaten Serang memiliki 29 kecamatan dan 326 desa dengan batas administrasi:

a) Sebelah Utara: Laut Jawa, Kota Cilegon, Kota Serang.

b) Sebelah Timur: Kabupaten Tangerang

c) Sebelah Barat: Kota Cilegon dan Selat Sunda

d) Sebelah Selatan: Kabupaten Lebak dan Kabupaten Pandeglang 


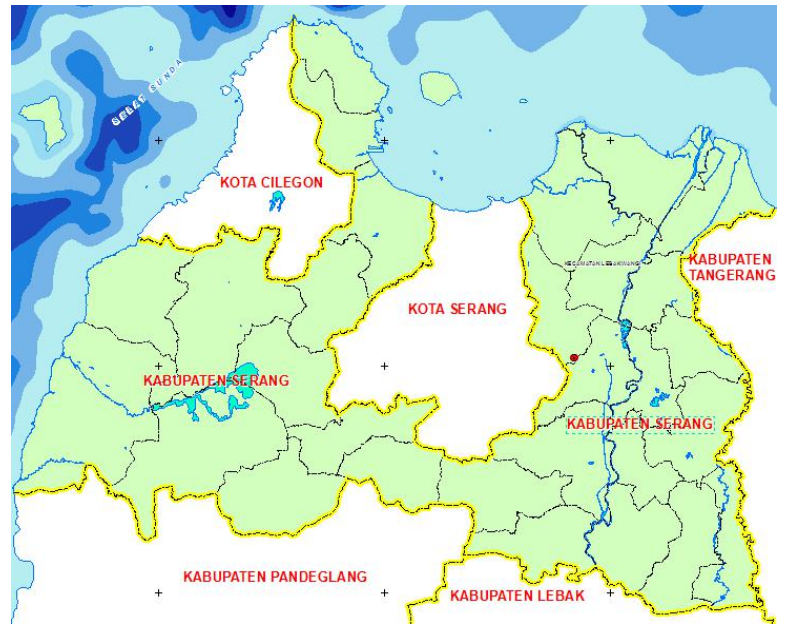

Gambar 1. Peta Administrasi Kabupaten Serang, Banten (Sumber: Pengolahan Data, 2019)

\subsection{Pengumpulan dan Pengolahan Data}

Untuk membangun model dispersi/persebaran gas dibutuhkan data kualitas udara ambien. Data tersebut diperoleh dari hasil pemantauan kualitas udara ambien yang dilakukan oleh Dinas Lingkungan Hidup Kabupaten Serang.

Data kualitas udara yang digunakan adalah data sekunder kualitas udara ambien dari tahun 2015 sampai 2019. Selama periode tersebut dilakukan pengukuran kualitas udara sebanyak 104 kegiatan pemantauan pada 78 lokasi pengamatan pemantauan di Kabupaten Serang.

Dari 78 lokasi tersebut, beberapa lokasi titik sampel memiliki koordinat yang tetap setiap tahun dan beberapa lokasi titik sampel lainnya memiliki koordinat yang berpindah-pindah. Data-data kualitas udara yang diperoleh tersebut dapat dikelompokkan pada tiga kondisi data berkaitan dengan informasi lokasi sebagai berikut:

a) Data kualitas udara ambien yang memiliki koordinat langsung digambarkan pada peta sesuai koordinatnya.

b) Data kualitas udara ambien yang tidak memiliki koordinat titik sampel namun memiliki informasi lokasi yang spesifik, perkiraan koordinatnya dapat diidentifikasi lokasinya berdasarkan informasi yang diperoleh dari peta google earth.

c) Data kualitas udara ambien yang tidak memiliki koordinat namun hanya memiliki informasi nama desa, diperkirakan dengan menggunakan teknik centroid pada perangkat lunak Arc Map pada setiap desa.
Dari 104 data pemantauan kualitas udara yang tersebar pada 78 lokasi pemantauan dari tahun 2015 hingga tahun 2019, dapat dikelompokkan menjadi 5 klaster regional (zona) yang dipertimbangkan berdasarkan kondisi topografi dan sebaran industrinya sebagaimana diperlihatkan pada Gambar 2.

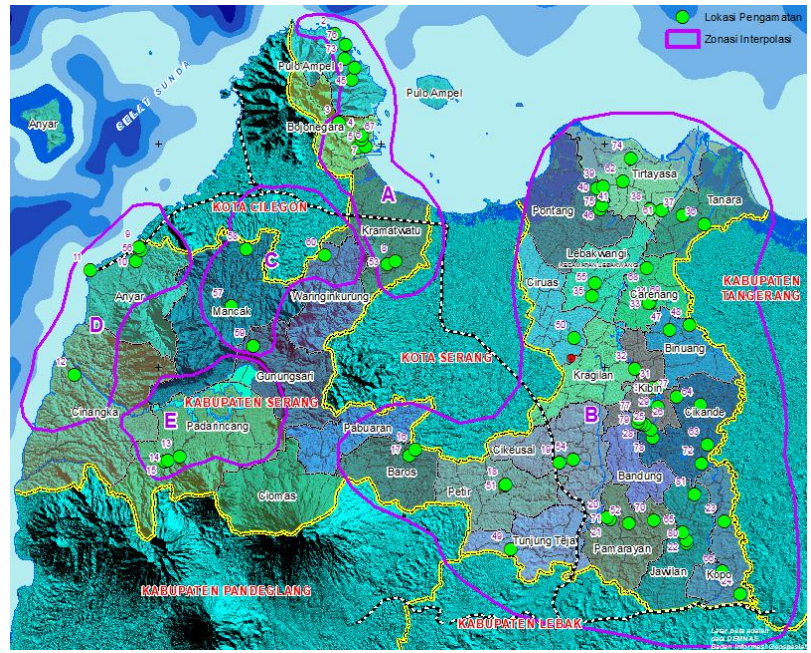

Gambar 2. Lokasi Pengamatan dan Klaster-

Regional Pemodelan Dispersi Gas dan Partikulat

Berdasarkan Kondisi Topografi dan Sebaran

Industri (Sumber: Pengolahan Data, 2019)

Pembagian zona didasarkan atas beberapa alasan dengan penjelasan bahwa zonasi (ring warna ungu) ditentukan berdasarkan 2 parameter:

1. Persebaran lokasi pengamatan kualitas udara yang telah dilakukan oleh DLH (Dinas Lingkungan Hidup) Kab Serang dari tahun 20152019.

2. Berdasarkan data DEMNAS (Digital Elevation Model Nasional) yang diperoleh dari instansi BIG (Badan Informasi Geospasial).

Zonasi ini dibuat untuk keperluan interpolasi dengan asumsi bahwa pengaruh arah dan kecepatan angin yang akan mempengaruhi kualitas udara dibatasi oleh topografi. Arah dan kecepatan angin tidak akan dapat membawa partikel kualitas udara melampaui topografi yang lebih tinggi seperti perbukitan atau pegunungan. Sehingga zonasi tersebut dibuat sebagai batas wilayah interpolasi data kualitas udara. Semua zona relatif datar hanya saja batas zona tersebut dibentuk karena adanya pembatas perbukitan/topografi tinggi sehingga pergerakan anginnya terbatas.

Selain pembagian berdasarkan klaster-klaster regional, model juga akan dikelompokkan berdasarkan musim. Dalam hal ini ketersediaan dan 
distribusi data menentukan jumlah musim yang akan digunakan dalam pemodelan.

\subsection{Metode Analisis}

\subsubsection{Metode Analisis Pola Dispersi Gas}

Setelah diketahui data sekunder konsentrasi polutan di beberapa titik yang berasal dari hasil pengukuran kualitas udara ambien di beberapa titik sampel selanjutnya dilakukan analisis data untuk mengetahui pola sebaran polutan di udara untuk parameter gas $\mathrm{NO}_{2}$ yang dianalisis. Pola sebaran polutan industri dianalisis dengan membuat kontur dispersi untuk parameter pencemar $\mathrm{NO}_{2}$. Kontur dispersi ini akan memberikan gambaran informasi mengenai nilai konsentrasi pada area penelitian melalui garis kontur yang saling terhubung pada area yang memiliki nilai konsentrasi yang sama (Isohyet). Pemodelan sebaran udara menggunakan Software Arcgis dengan hasil berupa peta.

Dalam konteks fenomena keruangan terdapat perbedaan kenampakan, struktur, pola, dan proses. Pola merupakan pola persebaran suatu fenomena di ruang muka bumi. Analisis keruangan mencoba menelaah tentang lokasi dan persebaran gejalagejala di ruang muka bumi. Untuk memperoleh gambaran sesuatu di muka bumi, atau untuk memberikan gambaran tentang sesuatu di muka bumi, alat yang terbaik adalah peta (Sandy, 1973).

Dalam analisis keruangan perlu dilakukan analisis kewilayahan. Wilayah pada hakekatnya menyangkut sebagian dari muka bumi yang batasnya ditetapkan atas dasar kriteria tertentu. Salah satu cara untuk melakukan analisis kewilayahan adalah dengan interpolasi.

Interpolasi adalah suatu metode atau fungsi matematika yang menduga nilai pada lokasi-lokasi yang datanya tidak tersedia. Interpolasi spasial mengasumsikan bahwa atribut data bersifat kontinu di dalam ruang (space) dan atribut ini saling berhubungan (dependence) secara spasial (Anderson dalam Prasasti et al., 2005). Kedua asumsi tersebut mengindikasikan bahwa pendugaan atribut data dapat dilakukan berdasarkan lokasi-lokasi di sekitarnya dan nilai pada titik-titik yang berdekatan akan lebih mirip daripada nilai pada titik-titik yang terpisah lebih jauh.

Metode geostatistik merupakan salah satu bentuk model yang dapat digunakan untuk menginterpolasikan nilai dari suatu variabel yang terdistribusi dalam ruang. Teknik interpolasi dengan model geostatistik lazim dilakukan untuk memperkirakan suatu nilai yang terdistribusi secara spasial pada titik yang tidak dapat diambil sampel yaitu dengan cara mengukur suatu nilai dari nilai yang berdekatan (Wahono, 2003). Untuk menduga nilai kualitas udara parameter gas $\mathrm{NO}_{2}$ di Kabupaten Serang, pada kajian ini digunakan metode geostatistik interpolasi spasial IDW (Inverse Distance Weighted). Metode ini dilakukan dengan menggunakan perangkat lunak Arc Map dengan mengkalkulasi nilai rata-rata parameter gas $\mathrm{NO}_{2}$ per musim selama tahun pengamatan $2015-2019$.

Metode ini memiliki asumsi bahwa setiap titik input mempunyai pengaruh yang bersifat lokal yang berkurang terhadap jarak. Metode IDW umumnya dipengaruhi oleh inverse jarak yang diperoleh dari persamaan matematika. Pada metode interpolasi ini dapat menyesuaikan pengaruh relatif dari titik-titik sampel. Nilai power pada interpolasi IDW ini menentukan pengaruh terhadap titik-titik masukan (input), dimana pengaruh akan lebih besar pada titik-titik yang lebih dekat sehingga menghasilkan permukaan yang lebih detail. Bobot yang digunakan untuk rata-rata adalah turunan fungsi jarak antara titik sampel dan titik yang diinterpolasi (Philip and Watson, 1982 dalam Merwade et al., 2006). Fungsi umum pembobotan adalah inverse dari kuadrat jarak dan persamaan ini digunakan pada metode Inverse Distance Weighted yang dirumuskan dalam formula berikut ini (Azpurua and Ramos, 2010):

$$
\begin{gathered}
Z^{*}=\sum_{i=1}^{N} \omega_{i} Z_{i} \\
\omega_{i}=\frac{h_{i}^{-D}}{\sum_{j=0}^{n} h_{j}^{-D}} \operatorname{Dimana} Z_{i}(i=1,2,3, \ldots, N)
\end{gathered}
$$

merupakan nilai ketinggian data yang ingin diinterpolasi sejumlah $\mathrm{N}$ titik, dan bobot (weight) $\omega_{i}$ yang dirumuskan sebagai:

$p$ adalah nilai positif yang dapat diubah-ubah yang disebut dengan parameter power (biasanya bernilai 2) dan $h_{i}$ merupakan jarak dari sebaran titik ke titik interpolasi yang dijabarkan sebagai:

$$
h_{i}=\sqrt{\left(x-x_{i}\right)^{2}+\left(y-y_{i}\right)^{2}}
$$

$(x, y)$ adalah koordinat titik interpolasi dan $\left(x_{i}, y_{i}\right)$ adalah koordinat untuk setiap sebaran titik. Fungsi peubah weight bervariasi untuk keseluruhan data sebaran titik sampai pada nilai yang mendekati nol dimana jarak bertambah terhadap sebaran titik.

Kelebihan dari metode interpolasi IDW ini adalah karakteristik interpolasi dapat dikontrol dengan membatasi titik-titik masukan yang digunakan dalam proses interpolasi. Titik-titik yang terletak jauh dari titik sampel dan yang diperkirakan 
memiliki korelasi spasial yang kecil atau bahkan tidak memiliki korelasi spasial dapat dihapus dari perhitungan. Titik-titik yang digunakan dapat ditentukan secara langsung, atau ditentukan berdasarkan jarak yang ingin diinterpolasi. Kelemahan dari interpolasi IDW adalah tidak dapat mengestimasi nilai di atas nilai maksimum dan dibawah nilai minimum dari titik-titik sampel (Pramono, 2008).

Kajian kali ini menggunakan metode variable search radius dalam penentuan luas daerah yang dipengaruhi titik sampel. Titik-titik yang digunakan dalam interpolasi ini ditentukan oleh user, sehingga nilai search radius bervariasi untuk setiap interpolasi. Hal ini bergantung pada seberapa jauh titik tersebut mencari sel-sel yang berada disekitarnya, sehingga beberapa bagian akan menjadi lebih besar dan beberapa bagian lain akan menjadi lebih kecil, tergantung pada kerapatan titiktitik di sekitar sel yang diinterpolasi (Watson and Philip,1985).

\subsubsection{Metode Analisis Dampak Terhadap Permukiman}

Hasil pemodelan sebaran $\mathrm{NO}_{2}$, akan ditampalkan dengan sebaran permukiman di Kabupaten Serang. Hal ini bertujuan untuk mengetahui dampak sebaran konsentrasi gas tersebut terhadap kawasan sebaran permukiman Kabupaten Serang (Gambar 3).

Rahmawati (1999) menganalisis pola sebaran polutan udara untuk tiap-tiap musim dan menginformasikan pada periode musim yang berbeda akan menghasilkan pola persebaran polutan yang berbeda pula.

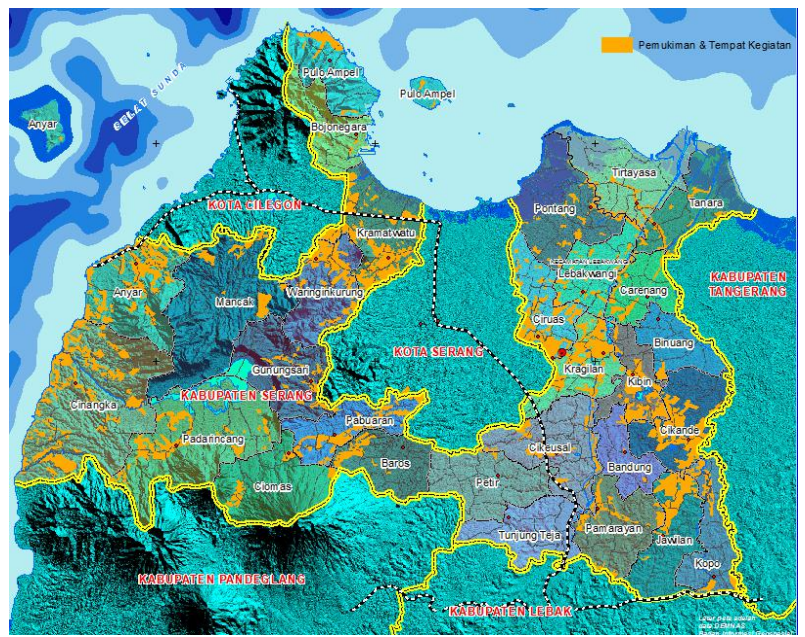

Gambar 3. Sebaran Lokasi Permukiman Kabupaten Serang. (Sumber: Revisi RTRW Kab. Serang 20112031)
Dampak terhadap permukiman sangat bergantung kepada kondisi meteorologis untuk setiap musim. Untuk itu digunakan diagram mawar angin untuk mengidentifikasi kawasan permukiman yang terkena dampak dari sebaran gas untuk setiap musimnya. Arah dan kecepatan angin menjadi pertimbangan dalam penentuan kawasan permukiman yang terkena dampak.

\section{HASIL DAN PEMBAHASAN}

\subsection{Analisa Wind Rose Kabupaten Serang}

Untuk melakukan analisis dampak pencemaran udara dari kegiatan usaha di Kabupaten Serang, dibutuhkan analisis arah dan kecepatan angin dominan untuk setiap musim. Arah angin dibutuhkan untuk menetapkan wilayah-wilayah permukiman mana saja yang akan terkena dampak.

Berdasarkan hasil wind rose pada musim barat dan musim timur diperoleh informasi bahwa frekuensi dominan kejadian angin barat di Kabupaten Serang mencapai 23\%, dengan kecepatan maksimum 8,8 $\mathrm{m} /$ detik. Selain angin barat terdapat pula kontribusi angin barat daya dan angin barat laut dengan frekuensi yang lebih kecil. Angin barat (Gambar 4) ini terjadi pada bulan Desember, Januari, dan Februari yang biasa disebut dengan musim barat (Wyrtki, 1961). Dengan demikian, wilayah permukiman yang kemungkinan terkena dampak dominan pencemaran udara berada di timur dan juga timur laut serta tenggara.

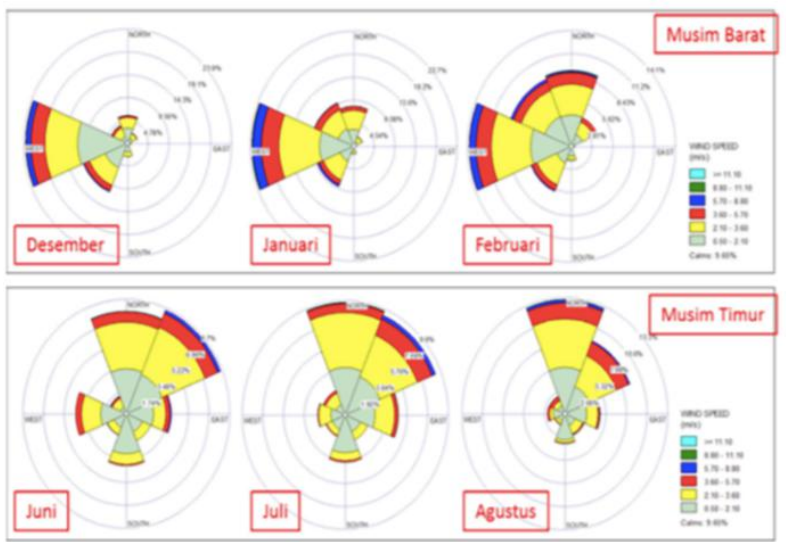

Gambar 4. Wind Rose di Kabupaten Serang. (Sumber: Wyrtki,1961)

Dominasi yang kedua adalah angin yang biasa disebut dengan musim angin yang bergerak dari arah utara dengan frekuensi kejadian mencapai $13 \%$ dengan kecepatan maksimum 8,8 m/detik. 
Selain angin utara, terdapat pula kontribusi angin timur laut dengan frekuensi yang lebih kecil. Angin ini terjadi pada bulan Juni, Juli, dan Agustus dan biasa disebut sebagai angin musim timur (Wyrtki, 1961). Pada kondisi ini wilayah permukiman yang kemungkinan terkena dampak dominan pencemaran udara berada di selatan dan juga barat daya.

Data kualitas udara dikelompokkan menjadi empat berdasarkan musim yaitu data pada saat angin musim barat (Desember-Februari); pada saat angin musim peralihan barat-timur (Maret-Mei); pada saat angin musim timur (Juni-Agustus); dan pada saat angin musim peralihan timur-barat (September-November).

\subsection{Pola Dispersi Spasial $\mathrm{NO}_{2}$ dan Dampaknya Terhadap Permukiman}

\subsubsection{Saat Angin Musim Barat (Desember- Februari)}

Baku mutu yang ditetapkan dalam Peraturan Pemerintah No. 41 Tahun 1999 tentang Pengendalian Pencemaran Udara untuk parameter $\mathrm{NO}_{2}$ adalah sebesar $400 \mu \mathrm{g} / \mathrm{Nm}^{3}$ untuk pengukuran selama 1 jam. Nilai konsentrasi $\mathrm{NO}_{2}$ tertinggi yang terukur selama angin musim barat adalah 50 $\mu \mathrm{g} / \mathrm{Nm}^{3}$. Hal ini menunjukkan bahwa selama angin musim barat dari tahun 2015 - 2019 tidak terukur konsentrasi $\mathrm{NO}_{2}$ yang melampaui baku mutu di semua titik pemantauan di Kabupaten Serang.

Berdasarkan hasil pemodelan sebaran gas $\mathrm{NO}_{2}$ selama angin musim barat 2015 - 2019 diperlihatkan gambaran pola dispersi gas $\mathrm{NO}_{2}$ yang sudah dibagi dalam Zona A, B, C, D, dan E sebagaimana diperlihatkan pada Gambar 5 (lima) di bawah ini. Dari hasil pemodelan tersebut terlihat bahwa konsentrasi $\mathrm{NO}_{2}$ di Zona $\mathrm{A}$ di Kecamatan Kramatwatu dan Bojonegara yang berada pada kisaran $20-30 \mu \mathrm{g} / \mathrm{Nm}^{3}$ relatif lebih tinggi daripada di bagian utara (Kecamatan Pulo Ampel) yang berkisar antara $10-20 \mu \mathrm{g} / \mathrm{Nm}^{3}$. Di Kecamatan Pulo Ampel banyak terdapat industri petrokimia yang memiliki potensi emisi gas $\mathrm{NO}_{2}$ ke udara ambien. Namun apabila diperhatikan pola angin selama angin musim barat yang dominan bertiup dari barat dan barat laut, maka konsentrasi $\mathrm{NO}_{2}$ yang teremisi ke udara akan terbawa ke arah laut dan mengalami pengenceran sehingga konsentrasi $\mathrm{NO}_{2}$ di Zona $\mathrm{A}$ relatif rendah.

Konsentrasi gas $\mathrm{NO}_{2}$ tertinggi $\left(40-50 \mu \mathrm{g} / \mathrm{Nm}^{3}\right)$ di zona B terkonsentrasi di sekitar zona industri Cikande, hal ini menunjukkan adanya kontribusi gas $\mathrm{NO}_{2}$ dari kegiatan usaha industri di sekitar kawasan industri Cikande. Dari pola dispersi gas $\mathrm{NO}_{2}$ di sekitar Cikande terlihat adanya kecenderungan persebaran gas $\mathrm{NO}_{2}$ ke arah timur yang menunjukkan adanya pengaruh pola angin selama musim barat yang bertiup dari barat ke timur. Namun radius persebarannya masih di sekitar Zona Indutri Cikande $( \pm 5 \mathrm{~km})$. Konsentrasi $\mathrm{NO}_{2}$ di bagian utara (Kecamatan Tirtayasa, Tanara, dan Lebakwangi) relatif lebih rendah daripada konsentrasi $\mathrm{NO}_{2}$ di bagian selatan, hal ini disebabkan oleh pengaruh angin laut yang lebih dominan di bagian utara.

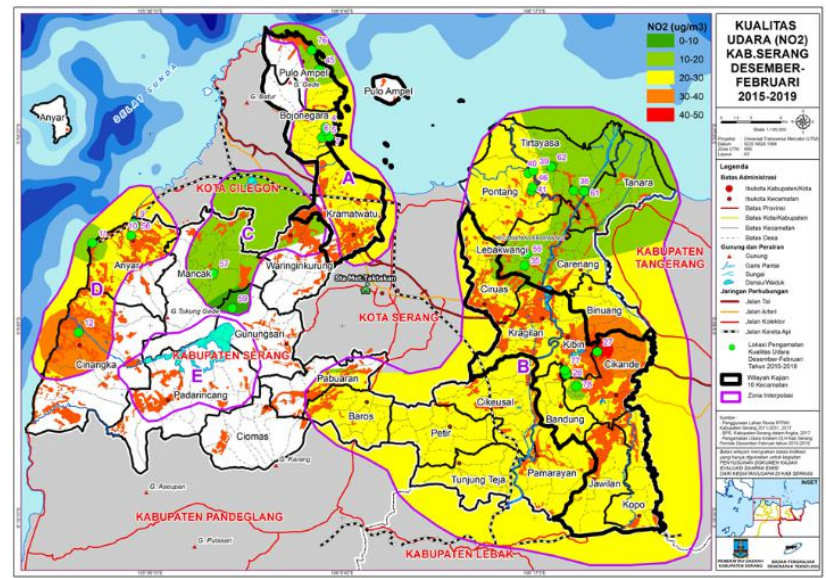

Gambar 5. Pemodelan Sebaran Gas $\mathrm{NO}_{2}$ pada Angin Musim Barat di Kabupaten Serang Tahun 2015 - 2019.

(Sumber: Hasil Analisis, 2019)

Pada zona $\mathrm{C}$ konsentrasi persebaran $\mathrm{NO}_{2}$ relatif rendah, konsentrasi maksimum berkisar antara 10$20 \mu \mathrm{g} / \mathrm{Nm}^{3}$, namun diperkirakan sumber $\mathrm{NO}_{2}$ yang terukur bukan berasal dari kegiatan usaha industri.

Pada zona $\mathrm{D}$ konsentrasi $\mathrm{NO}_{2}$ tertinggi di sekitar kantor Kecamatan Anyer karena tingginya aktivitas perekonomian di lokasi tersebut. Konsentrasi $\mathrm{NO}_{2}$ ini menurun ke arah utara. Di zona $\mathrm{D}$ tidak ditemukan adanya kegiatan industri dan sebagian besar sumber $\mathrm{NO}_{2}$ di area ini berasal dari sektor transportasi. Pada saat angin musim barat (Desember-Februari) tidak terdapat titik sampel pada zona $\mathrm{E}$.

Pada zona A mayoritas berwarna kuning (memiliki nilai $\mathrm{NO}_{2}$ yang berkisar antara 20-30 $\mu \mathrm{g} / \mathrm{Nm}^{3}$ ). Pada zona B mayoritas berwarna kuning (memiliki nilai $\mathrm{NO}_{2}$ dan berkisar antara 20-30 $\left.\mu \mathrm{g} / \mathrm{Nm}^{3}\right)$ dan Hijau Muda $\left(10-20 \mu \mathrm{g} / \mathrm{Nm}^{3}\right)$. Pada Zona C mayoritas berwarna Hijau Muda (10-20 $\mu \mathrm{g} / \mathrm{Nm}^{3}$ ). Dan pada zona $\mathrm{D}$ mayoritas berwarna kuning (memiliki nilai $\mathrm{NO}_{2}$ berkisar antara 20-30 $\mu \mathrm{g} / \mathrm{Nm}^{3}$ ) dan Orange $\left(30-40 \mu \mathrm{g} / \mathrm{Nm}^{3}\right)$. Pada peta sebaran tersebut dapat diketahui bahwa tidak ada daerah yang gas $\mathrm{NO}_{2}$ nya melebihi ambang baku mutu. Akan tetapi pada zona $D$ terdapat daerah 
yang nilainya lebih tinggi dan lebih luas dibanding wilayah lainnya. Berdasarkan hasil pemodelan di atas dapat dihitung luas permukiman terdampak gas $\mathrm{NO}_{2}$ berdasarkan rentang konsentrasi gas $\mathrm{NO}_{2}$ yang digunakan dalam model.

Tabel 1 (satu) menunjukkan bahwa pada angin musim barat terdapat beberapa daerah permukiman di kecamatan wilayah kajian yang terdampak dari sebaran gas $\mathrm{NO}_{2}$. Permukiman paling luas yang terdampak oleh gas $\mathrm{NO}_{2}$ dengan nilai paling tinggi berada pada Kecamatan Cikande, yaitu 396,40 $\mathrm{Ha}$ $\left(40-50 \mu \mathrm{g} / \mathrm{Nm}^{3}\right)$ dan 1595,33 $\mathrm{Ha}\left(30-40 \mu \mathrm{g} / \mathrm{Nm}^{3}\right)$.

Tabel 1. Luas Permukiman Terdampak (Ha) pada Rentang Kualitas Udara $\mathrm{NO}_{2}\left(\mu \mathrm{g} / \mathrm{Nm}^{3}\right)$ Periode Desember-Februari Tahun 2015-2019

\begin{tabular}{l|r|r|r|r|r}
\hline Kecamatan & $\mathbf{1 0 - 2 0}$ & $\mathbf{2 0 - 3 0}$ & $\mathbf{3 0 - 4 0}$ & $\mathbf{4 0 - 5 0}$ & \multicolumn{1}{c}{ Total } \\
\hline Bandung & & 2525,47 & & & 2525,47 \\
\hline Bojonegara & 41,40 & 1977,98 & 52,54 & & 2071,93 \\
\hline Cikande & 341,43 & 2521,07 & 1595,33 & 396,40 & 4854,22 \\
\hline Ciruas & 1127,42 & 3195,68 & & & 4323,10 \\
\hline Jawilan & & 4437,10 & & & 4437,10 \\
\hline Kibin & 0,31 & 2376,29 & 514,18 & 104,61 & 2995,38 \\
\hline Kopo & & 3785,91 & & & 3785,91 \\
\hline Kragilan & 677,73 & 3779,70 & & & 4457,43 \\
\hline Kramatwatu & 307,83 & 4489,43 & & & 4797,26 \\
\hline Pulo Ampel & 1072,66 & 935,51 & & & 2008,17 \\
\hline \multicolumn{1}{c}{ Total } & 3568,77 & 30024,14 & 2162,05 & 501,00 & 36255,96 \\
\hline (Sumber: Pengolahan Data,
\end{tabular}

(Sumber: Pengolahan Data, 2019)

\subsubsection{Saat Angin Musim Peralihan Barat - Timur (Maret-Mei)}

Apabila dibandingkan dengan baku mutu yang ditetapkan dalam Peraturan Pemerintah No. 41 Tahun 1999 tentang Pengendalian Pencemaran Udara untuk parameter $\mathrm{NO}_{2}$ adalah sebesar 400 $\mu \mathrm{g} / \mathrm{Nm}^{3}$ untuk pengukuran selama 1 jam. Nilai konsentrasi $\mathrm{NO}_{2}$ tertinggi yang terukur selama angin musim peralihan barat-timur adalah $50 \mu \mathrm{g} / \mathrm{Nm}^{3}$ di Kecamatan Kibin. Hal ini menunjukkan bahwa selama angin musim barat dari tahun 2015 - 2019 tidak terukur konsentrasi $\mathrm{NO}_{2}$ yang melampaui baku mutu di semua titik pemantuan di Kabupaten Serang.

Berdasarkan hasil pemodelan sebaran gas $\mathrm{NO}_{2}$ selama angin musim peralihan barat-timur tahun 2015-2019 diperlihatkan gambaran pola dispersi gas $\mathrm{NO}_{2}$ yang sudah dibagi dalam Zona $\mathrm{A}, \mathrm{B}, \mathrm{C}, \mathrm{D}$, dan $\mathrm{E}$ sebagaimana diperlihatkan pada Gambar 6 (enam) di bawah ini. Pada musim peralihan barat (Maret-Mei) tidak terdapat titik sampel pada zona C dan D sebagaimana diperlihatkan pada Gambar 6.

Dari hasil pemodelan tersebut terlihat bahwa konsentrasi $\mathrm{NO}_{2}$ di Zona $\mathrm{A}$ di Kecamatan Kramatwatu dan Bojonegara sebagian berada pada kisaran 20-30 $\mu \mathrm{g} / \mathrm{Nm}^{3}$ dan sebagian lagi berada pada kisaran $30-40 \mu \mathrm{g} / \mathrm{Nm}^{3}$. Kedua kisaran tersebut relatif lebih tinggi daripada di bagian utara (Kecamatan Pulo Ampel) yang hanya berkisar antara $10-20 \mu \mathrm{g} / \mathrm{Nm}^{3}$ dan $20-30 \mu \mathrm{g} / \mathrm{Nm}^{3}$. Meskipun di Kecamatan Pulo Ampel banyak terdapat industri petrokimia yang memiliki potensi emisi gas $\mathrm{NO}_{2} \mathrm{ke}$ udara ambien, namun tidak nampak adanya kontribusi emisi gas $\mathrm{NO}_{2}$ di Kecamatan Pulo Ampel. Namun apabila diperhatikan posisi Kecamatan Pulo Ampel yang berada di pesisir paling utara, maka konsentrasi $\mathrm{NO}_{2}$ yang teremisi ke udara akan mudah terbawa ke arah laut dan mengalami pengenceran sehingga konsentrasi $\mathrm{NO}_{2}$ di Zona $\mathrm{A}$ relatif rendah dibandingkan dengan bagian selatan.

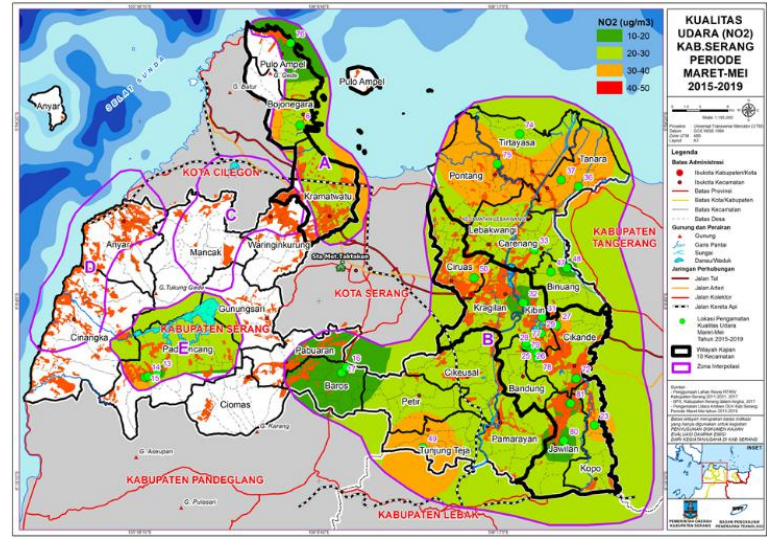

Gambar 6. Pemodelan Sebaran Gas $\mathrm{NO}_{2}$ pada Angin Musim Peralihan Barat - Timur

di Kabupaten Serang Tahun 2015 - 2019.

(Sumber: Hasil Analisis, 2019)

Konsentrasi gas $\mathrm{NO}_{2}$ tertinggi sebesar 40-50 $\mu \mathrm{g} / \mathrm{Nm}^{3}$ terkonsentrasi di Kecamatan Kibin dan sebesar $30-40 \mu \mathrm{g} / \mathrm{Nm}^{3}$ di zona B terkonsentrasi di sekitar zona industri Cikande dengan persebaran yang tidak terlalu luas pada saat angin musim peralihan barat-timur, hal ini menunjukkan adanya sedikit kontribusi gas $\mathrm{NO}_{2}$ dari kegiatan usaha industri di sekitar zona industri Kibin dan Cikande, namun tidak menimbulkan sebaran gas yang relatif tidak luas. Konsentrasi $\mathrm{NO}_{2}$ yang berkisar 30-40 $\mu \mathrm{g} / \mathrm{Nm}^{3}$ di bagian utara (Kecamatan Tirtayasa, Tanara, dan Pontang) yang relatif tinggi daripada kecamatan disekitarnya, menunjukkan adanya kontribusi $\mathrm{NO}_{2}$ pada saat angin musim peralihan barat dan timur dari kegiatan non-industri.

Pada zona $\mathrm{E}$ konsentrasi $\mathrm{NO}_{2}$ sebagian besar berada pada kisaran $20-30 \mu \mathrm{g} / \mathrm{Nm}^{3}$ dan sebagian kecil berada pada kisaran $30-40 \mu \mathrm{g} / \mathrm{Nm}^{3}$ di bagian selatan. Konsentrasi $\mathrm{NO}_{2}$ ini kemungkinan 
diemisikan dari kegiatan non-industri karena tidak ditemukan kegiatan industri yang signifikan memberikan dampak emisi gas $\mathrm{NO}_{2}$.

Pada zona A mayoritas berwarna hijau muda $\left(20-30 \mu \mathrm{g} / \mathrm{Nm}^{3}\right)$ dan hijau tua $\left(10-20 \mu \mathrm{g} / \mathrm{Nm}^{3}\right)$. Pada zona B mayoritas berwarna hijau muda (20-30 $\left.\mu \mathrm{g} / \mathrm{Nm}^{3}\right)$ dan orange $\left(30-40 \mu \mathrm{g} / \mathrm{Nm}^{3}\right)$. Pada zona $\mathrm{E}$ mayoritas berwarna Hijau Muda $\left(20-30 \mu \mathrm{g} / \mathrm{Nm}^{3}\right)$. Pada peta sebaran tersebut dapat diketahui bahwa tidak ada daerah yang gas $\mathrm{NO}_{2}$ nya melebihi ambang baku mutu. Akan tetapi, pada zona B terdapat daerah yang nilainya lebih tinggi dan lebih luas dibanding wilayah lainnya. Berdasarkan hasil pemodelan di atas dapat dihitung luas permukiman terdampak gas $\mathrm{NO}_{2}$ berdasarkan rentang konsentrasi gas $\mathrm{NO}_{2}$ yang digunakan dalam model.

Tabel 2 (dua) menunjukkan bahwa pada saat angin musim peralihan barat-timur terdapat beberapa daerah permukiman di kecamatan wilayah kajian yang terdampak dari sebaran gas $\mathrm{NO}_{2}$. Permukiman paling luas yang terdampak oleh gas $\mathrm{NO}_{2}$ dengan nilai paling tinggi berada pada Kecamatan Kibin, yaitu seluas 4,72 Ha (40-50 $\left.\mu \mathrm{g} / \mathrm{Nm}^{3}\right)$ dan Kecamatan Ciruas $804 \mathrm{Ha}(30-40$ $\mu \mathrm{g} / \mathrm{Nm}^{3}$ ).

Tabel 2. Luas Permukiman Terdampak ( $\mathrm{Ha})$ pada Rentang Kualitas Udara $\mathrm{NO}_{2}\left(\mu \mathrm{g} / \mathrm{Nm}^{3}\right)$ Periode Maret-Mei Tahun 2015- 2019

\begin{tabular}{c|c|c|c|c|c}
\hline Kecamatan & $\mathbf{1 0 - 2 0}$ & $\mathbf{2 0 - 3 0}$ & $\mathbf{3 0 - 4 0}$ & $\mathbf{4 0 - 5 0}$ & Total \\
\hline Bandung & & 2525,47 & & & 2525,47 \\
\hline Bojonegara & & 1546,32 & 521,13 & & 2067,45 \\
\hline Cikande & 395,74 & 4077,39 & 381,08 & & 4854,22 \\
\hline Ciruas & & 3519,69 & 804,00 & & 4323,69 \\
\hline Jawilan & 1733,61 & 2661,01 & 42,49 & & 4437,10 \\
\hline Kibin & 565,39 & 2340,68 & 84,59 & 4,72 & 2995,38 \\
\hline Kopo & 97,75 & 3134,61 & 553,55 & & 3785,91 \\
\hline Kragilan & 295,48 & 4084,59 & 77,36 & & 4457,43 \\
\hline Kramatwatu & 4,72 & 4037,84 & 448,07 & & 4490,64 \\
\hline Pulo Ampel & 1291,85 & 710,34 & 10,46 & & 2012,66 \\
\hline Total & 4384,55 & 28637,93 & 2922,73 & 4,72 & 35949,93 \\
\hline Sumber : Pengolah
\end{tabular}

(Sumber : Pengolahan Data,2019)

\subsubsection{Saat Angin Musim Timur (Juni-Agustus)}

Nilai konsentrasi $\mathrm{NO}_{2}$ tertinggi yang terukur selama angin musim timur berkisar pada rentang 30-40 $\mathrm{\mu g} / \mathrm{Nm}^{3}$ yaitu di Kecamatan Petir dan Bojonegara. Baku mutu yang ditetapkan dalam Peraturan Pemerintah No. 41 Tahun 1999 tentang Pengendalian Pencemaran Udara untuk parameter $\mathrm{NO}_{2}$ adalah sebesar $400 \mu \mathrm{g} / \mathrm{Nm}^{3}$ untuk pengukuran selama 1 jam. Hal ini menunjukkan bahwa selama angin musim timur dari tahun 2015-2019 tidak terukur konsentrasi $\mathrm{NO}_{2}$ yang melampaui baku mutu di semua titik pemantauan di Kabupaten Serang.

Berdasarkan hasil pemodelan sebaran gas $\mathrm{NO}_{2}$ untuk angin musim timur 2015 - 2019 diperlihatkan gambaran pola dispersi gas $\mathrm{NO}_{2}$ yang sudah dibagi dalam Zona A, B, C, D, dan E sebagaimana diperlihatkan pada Gambar 7 (tujuh) di bawah ini. Pada angin musim timur (Juni-Agustus) tidak terdapat titik sampel pada zona C, D, dan E.

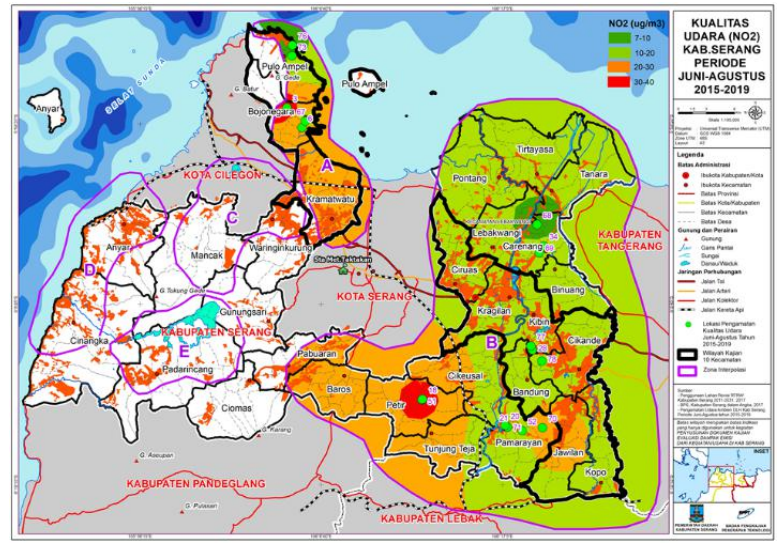

Gambar 7. Pemodelan Sebaran Gas $\mathrm{NO}_{2}$ pada Angin Musim Timur

di Kabupaten Serang Tahun 2015 - 2019.

(Sumber: Hasil Analisis, 2019)

Dari hasil pemodelan tersebut terlihat bahwa konsentrasi $\mathrm{NO}_{2}$ di zona $\mathrm{A}$ di Kecamatan Kramatwatu yang berada pada kisaran 20-30 $\mu \mathrm{g} / \mathrm{Nm}^{3}$ dan Bojonegara yang berada pada kisaran 30-40 $\mu \mathrm{g} / \mathrm{Nm}^{3}$. Konsentrasi $\mathrm{NO}_{2}$ di Kecamatan Kramatwatu dan Bojonegara tersebut relatif lebih tinggi daripada di bagian utara (Kecamatan Pulo Ampel) yang maksimum hanya $20 \mu \mathrm{g} / \mathrm{Nm}^{3}$. Di Kecamatan Pulo Ampel banyak terdapat industri petrokimia yang memiliki potensi emisi gas $\mathrm{NO}_{2}$ ke udara ambien akan tetapi tidak berkontribusi meningkatkan konsentrasi $\mathrm{NO}_{2}$. Apabila diperhatikan pola angin selama angin musim barat yang dominan bertiup dari barat dan barat laut, maka konsentrasi $\mathrm{NO}_{2}$ yang teremisi ke udara akan terbawa ke arah laut dan mengalami pengenceran sehingga konsentrasi $\mathrm{NO}_{2}$ di bagian utara zona $\mathrm{A}$ relatif rendah daripada bagian selatan.

Konsentrasi gas $\mathrm{NO}_{2}$ di zona $\mathrm{B}$ sekitar zona industri Cikande pada musim timur cenderung merata tidak memperlihatkan lebih tinggi daripada kecamatan-kecamatan disekitarnya. Hal ini menunjukkan bahwa tidak teridentifikasi adanya kontribusi sumber emisi gas $\mathrm{NO}_{2}$ dari zona industri Serang Barat selama angin musim timur 2015 2019. Konsentrasi $\mathrm{NO}_{2}$ yang tinggi di sekitar 
Kecamatan Petir diperkirakan bukan berasal dari kegiatan usaha industri.

Tabel 3. Luas Pemukiman Terdampak (Ha) pada Rentang Kualitas Udara $\mathrm{NO}_{2}\left(\mu \mathrm{g} / \mathrm{Nm}^{3}\right)$ Periode Juni-Agustus Tahun $2015-2019$

\begin{tabular}{l|r|r|r|r|r}
\hline Kecamatan & \multicolumn{1}{|c|}{$\mathbf{1 0 - 2 0}$} & $\mathbf{2 0 - 3 0}$ & $\mathbf{3 0 - 4 0}$ & $\mathbf{7 - 1 0}$ & \multicolumn{1}{c}{ Total } \\
\hline Bandung & 2378,07 & 147,39 & & & 2525,47 \\
\hline Bojonegara & 200,78 & 1454,77 & $\mathbf{4 0 9 , 8 5}$ & & 2065,40 \\
\hline Cikande & 4854,22 & & & & 4854,22 \\
\hline Ciruas & 4323,10 & & & & 4323,10 \\
\hline Jawilan & 2165,71 & 2271,39 & & & 4437,10 \\
\hline Kibin & 2995,38 & & & & 2995,38 \\
\hline Kopo & 3766,09 & 19,82 & & & 3785,91 \\
\hline Kragilan & 4093,72 & 363,71 & & & 4457,43 \\
\hline Kramatwatu & 23,61 & 4464,73 & & & 4488,34 \\
\hline Pulo Ampel & 825,37 & 627,07 & 86,88 & 443,59 & 1982,92 \\
\hline \multicolumn{1}{c|}{ Total } & $\mathbf{2 5 6 2 6 , 0 5}$ & $\mathbf{9 3 4 8 , 8 8}$ & $\mathbf{4 9 6 , 7 3}$ & $\mathbf{4 4 3 , 5 9}$ & $\mathbf{3 5 9 1 5 , 2 6}$ \\
\hline
\end{tabular}

(Sumber: Pengolahan Data, 2019)

Gambar pola sebaran gas $\mathrm{NO}_{2}$ pada saat angin musim timur di atas merupakan pola dispersi gas $\mathrm{NO}_{2}$ yang sudah dibagi dalam zona $\mathrm{A}, \mathrm{B}, \mathrm{C}, \mathrm{D}$, dan E. Pada zona A mayoritas berwarna orange (20-30 $\mu \mathrm{g} / \mathrm{Nm}^{3}$ ). Pada zona B mayoritas berwarna hijau muda $\left(10-20 \mu \mathrm{g} / \mathrm{Nm}^{3}\right)$ dan berwarna orange (20-30 $\mu \mathrm{g} / \mathrm{Nm}^{3}$ ). Akan tetapi, pada zona B terdapat daerah yang nilainya lebih tinggi dibanding wilayah lainnya (berwarna merah dengan nilai $30-40 \mu \mathrm{g} / \mathrm{Nm}^{3}$ ). Luas permukiman yang terdampak gas $\mathrm{NO}_{2}$ selama angin musim timur berdasarkan konsentrasi yang digunakan dalam model diperlihatkan pada Tabel 3 (tiga).

Tabel 3 (tiga) menunjukkan bahwa pada saat angin musim timur terdapat beberapa daerah permukiman di kecamatan wilayah kajian yang terdampak dari sebaran gas $\mathrm{NO}_{2}$. Permukiman paling luas yang terdampak oleh gas $\mathrm{NO}_{2}$ dengan nilai paling tinggi berada pada Kecamatan Bojonegara, yaitu seluas 409,85 $\mathrm{Ha}\left(30-40 \mu \mathrm{g} / \mathrm{Nm}^{3}\right)$.

\subsubsection{Saat Angin Musim Peralihan Timur-Barat (September-November)}

Baku mutu yang ditetapkan dalam Peraturan Pemerintah No. 41 Tahun 1999 tentang Pengendalian Pencemaran Udara untuk parameter $\mathrm{NO}_{2}$ adalah sebesar $400 \mu \mathrm{g} / \mathrm{Nm}^{3}$ untuk pengukuran selama 1 jam. Nilai konsentrasi $\mathrm{NO}_{2}$ tertinggi yang terukur selama angin musim peralihan timur-barat adalah 30-40 $\mu \mathrm{g} / \mathrm{Nm}^{3}$ di Kecamatan Kramatwatu dan Cikande. Hal ini menunjukkan bahwa selama angin musim barat dari tahun 2015 - 2019 tidak terukur konsentrasi $\mathrm{NO}_{2}$ yang melampaui baku mutu di semua titik pemantuan di Kabupaten Serang.

Berdasarkan hasil pemodelan sebaran gas $\mathrm{NO}_{2}$ selama angin musim peralihan timur-barat tahun 2015 - 2019 diperlihatkan gambaran pola dispersi gas $\mathrm{NO}_{2}$ yang sudah dibagi dalam zona $\mathrm{A}, \mathrm{B}, \mathrm{C}, \mathrm{D}$, dan $E$ sebagaimana diperlihatkan pada Gambar 8 (delapan) di bawah ini. Pada angin musim peralihan timur-barat (September-November) tidak terdapat titik sampel pada zona $\mathrm{C}, \mathrm{D}$, dan $\mathrm{E}$.

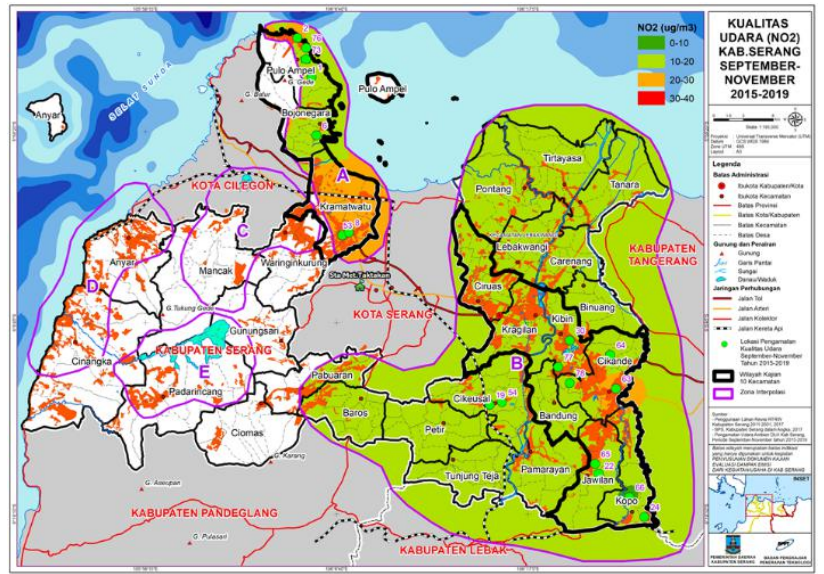

Gambar 8. Pemodelan Sebaran Gas NO2 pada Angin Musim Peralihan Timur - Barat di Kabupaten Serang Tahun 2015 - 2019.

(Sumber: Hasil Analisis, 2019)

Dari hasil pemodelan tersebut terlihat bahwa konsentrasi $\mathrm{NO}_{2}$ di zona $\mathrm{A}$ di Kecamatan Kramatwatu yang berada pada kisaran 20-30 $\mu \mathrm{g} / \mathrm{Nm}^{3}$. Konsentrasi $\mathrm{NO}_{2}$ di Kecamatan Kramatwatu tersebut relatif lebih tinggi daripada di bagian utara (Kecamatan Bojonegara dan Pulo Ampel) yang maksimum hanya $10-20 \mu \mathrm{g} / \mathrm{Nm}^{3}$. Di Kecamatan Pulo Ampel banyak terdapat industri petrokimia yang memiliki potensi emisi gas $\mathrm{NO}_{2}$ ke udara ambien akan tetapi tidak berkontribusi meningkatkan konsentrasi $\mathrm{NO}_{2}$ pada saat angin musim peralihan timur-barat. Keberadaan posisi industri yang berada di Pulo Ampel dan Bojonegara di pinggir pantai mengakibatkan konsentrasi $\mathrm{NO}_{2}$ yang teremisi ke udara akan terbawa ke arah laut dan mengalami pengenceran sehingga konsentrasi $\mathrm{NO}_{2}$ di bagian utara Zona A (Kecamatan Pulo Ampel dan Bojonegara) relatif rendah daripada bagian selatan. Konsentrasi gas $\mathrm{NO}_{2}$ di zona $\mathrm{B}$ pada saat angin musim peralihan timur-barat cenderung merata di seluruh kecamatan, kecuali di Kecamatan Cikande. Hal ini menunjukkan adanya sedikit kontribusi sumber emisi gas $\mathrm{NO}_{2}$ dari zona industri Serang Barat selama angin musim 
peralihan timur-barat 2015 - 2019, meskipun persebarannya tidak terlalu luas.

Pola persebaran konsentrasi gas $\mathrm{NO}_{2}$ pada saat angin musim peralihan timur-barat terbagi atas beberapa zona, dimana pada zona A mayoritas berwarna hijau muda $\left(10-20 \mu \mathrm{g} / \mathrm{Nm}^{3}\right)$ dan orange $\left(20-30 \mu \mathrm{g} / \mathrm{Nm}^{3}\right)$. Pada zona B mayoritas berwarna hijau muda $\left(10-20 \mu \mathrm{g} / \mathrm{Nm}^{3}\right)$. Pada peta sebaran tersebut dapat diketahui bahwa tidak ada daerah yang gas $\mathrm{NO}_{2}$-nya melebihi ambang baku mutu. Akan tetapi, pada zona A terdapat daerah yang nilainya lebih tinggi dan luas dibanding wilayah lainnya (berwarna orange dengan nilai 20-30 $\mu \mathrm{g} / \mathrm{Nm}^{3}$ ). Luas permukiman yang terdampak gas $\mathrm{NO}_{2}$ selama angin musim peralihan timur-barat berdasarkan konsentrasi yang digunakan dalam model diperlihatkan pada Tabel 4 (empat).

Tabel 4 (empat) di atas menunjukkan bahwa pada musim peralihan timur terdapat beberapa daerah permukiman di kecamatan wilayah kajian yang terdampak dari sebaran gas $\mathrm{NO}_{2}$. Permukiman paling luas yang terdampak oleh gas $\mathrm{NO}_{2}$ dengan nilai paling tinggi berada pada Kecamatan Kramatwatu, yaitu seluas 47,21 $\mathrm{Ha}$ (30$\left.40 \mu \mathrm{g} / \mathrm{Nm}^{3}\right)$ dan 4153,42 $\mathrm{Ha}\left(20-30 \mu \mathrm{g} / \mathrm{Nm}^{3}\right)$.

Tabel 4. Luas Permukiman Terdampak ( $\mathrm{Ha}$ ) pada Rentang Kualitas Udara $\mathrm{NO}_{2}\left(\mu \mathrm{g} / \mathrm{Nm}^{3}\right)$ Periode September-November Tahun 2015 - 2019

\begin{tabular}{l|r|r|r|r|r}
\hline \multicolumn{1}{c|}{ Kecamatan } & $\mathbf{0 - 1 0}$ & $\mathbf{1 0 - 2 0}$ & $\mathbf{2 0 - 3 0}$ & $\mathbf{3 0 - 4 0}$ & \multicolumn{1}{c}{ Total } \\
\hline Bandung & & 2525,47 & & & 2525,47 \\
\hline Bojonegara & & 1940,42 & 118,48 & & 2058,90 \\
\hline Cikande & & 3881,39 & 972,82 & & 4854,22 \\
\hline Ciruas & & 4323,10 & & & 4323,10 \\
\hline Jawilan & 8,63 & 4266,85 & 161,62 & & 4437,10 \\
\hline Kibin & & 2995,38 & & & 2995,38 \\
\hline Kopo & 329,23 & 3235,46 & 217,99 & & 3782,68 \\
\hline Kragilan & & 4457,43 & & & 4457,43 \\
\hline Kramatwatu & & 290,18 & $\mathbf{4 1 5 3 , 4 2}$ & $\mathbf{4 7 , 2 1}$ & 4490,82 \\
\hline Pulo Ampel & 76,26 & 1743,58 & 282,19 & & 2102,03 \\
\hline \multicolumn{7}{c}{ Total } & $\mathbf{4 1 4 , 1 2}$ & $\mathbf{2 9 6 5 9 , 2 5}$ & $\mathbf{5 9 0 6 , 5 4}$ & $\mathbf{4 7 , 2 1}$ & $\mathbf{3 6 0 2 7 , 1 2}$ \\
\hline (Sumber: Peng
\end{tabular}

(Sumber: Pengolahan Data, 2019)

\section{KESIMPULAN}

1. Berdasarkan hasil pengukuran kualitas udara ambien di Kabupaten Serang yang telah diukur oleh Dinas Lingkungan Hidup Kabupaten Serang dari tahun 2015 - 2019 untuk parameter $\mathrm{NO}_{2}$, terlihat bahwa tidak ada satupun yang melampaui baku mutu PP No. 41 Tahun 1999 tentang Pengendalian Pencemaran Udara.
2. Berdasarkan hasil pemodelan dispersi gas menunjukkan adanya suatu kecenderungan bahwa konsetrasi gas relatif tinggi pada zonazona industri, yang menunjukkan adanya kontribusi gas-gas dari kegiatan usaha industri pada beberapa angin musim yaitu angin musim barat, peralihan barat-timur, musim timur dan peralihan timur-barat.

3. Permukiman paling luas yang terdampak oleh gas $\mathrm{NO}_{2}$ dengan nilai paling tinggi (40-50 $\mu \mathrm{g} / \mathrm{Nm}^{3}$ ) berada pada Kecamatan Cikande, yaitu 396,40 $\mathrm{Ha}$. Begitupun dengan nilai gas $\mathrm{NO}_{2}$ sebesar $30-40 \mu \mathrm{g} / \mathrm{Nm}^{3}$ seluas $1595,33 \mathrm{Ha}$ juga berada di Kecamatan Cikande. Keduanya terjadi pada saat angin musim barat (Desember-Februari).

\section{PERSANTUNAN}

Terima kasih Kami sampaikan kepada Dinas Lingkungan Hidup (DLH) Kabupaten Serang atas segala dukungan moril maupun materil terhadap pemenuhan data pada kajian ini. Tulisan ini adalah sebagian hasil dari kerjasama antara Pusyantek BPPT dengan DLH Kabupaten Serang dengan Nomor Kontrak: SPK/11-JK.11/KPA-DLH/2019 dan 120/PKS/PB/BPPT/VIII/2019.

\section{DAFTAR PUSTAKA}

Azpurua, M.A. and K.D. Ramos. 2010. A Comparison of Spatial Interpolation Methods for Estimation of Average Electromagnetic Field Magnitude. Progress in Electromagnetics Research, 14, 135-145. https://doi.org/10.2528/PIERM1008310 3

Kementrian Lingkungan Hidup. 2004. Status Lingkungan Hidup Daerah 2004. Jakarta: KLH. Kementrian Lingkungan Hidup. 2008. Status Lingkungan Hidup Indonesia2008. Jakarta: $\mathrm{KLH}$.

Kementrian Lingkungan Hidup. 2009. Modul Diklat Pengendalian Pencemaran Udara Evaluasi Data Hasil Pemantauan Kualitas Udara. Jakarta: Penerbit Pusat Pendidikan dan Pelatihan.

Merwade, V. M., D.R. Maidment, and J. A. Golff. 2006. Anisotropic Consi-derations while Interpolating River Channel Bathymetry. Journal of Hydrology, 331: 731-741.

Muhammad, A. dan B. Nurbianto. 2006. Jakarta Kota Polusi (menggugat hak atas udara bersih). Jakarta: LP3S. 
Pramono, G. 2008. Akurasi Metode IDW dan Kriging Untuk Interpolasi Sebaran Sedimen Tersuspensi. Jurnal Forum Geografi Hal 97110. Bogor: Bakosurtanal.

Prasasti, I., H. Wijayanto, dan M. Christanto. 2005. Analisis Penerapan Metode Kriging dan Invers Distance Pada Interpolasi Data Dugaan Suhu, Air Mampu Curah (AMC) dan Indeks stabilitas Atmosfer (ISA) dari Data NOAA-TOVS. Jurnal Pertemuan IImiah Tahunan MAPIN, XIV: 316-317. Surabaya: ITSN.

Rahmawati, F. 1999. Kualitas Udara di Jakarta Tahun 1997. Skripsi. Depok: Departemen Geografi FMIPA UI.

Sandy, I.M. 1973. Esensi Geografi. Depok: Jurusan Georafi FMIPA-UI.

Wahono, G. 2003. Kajian Dinamika Spatial Zat Pencemar Udara (Studi Kasusdi Lokasi PT. National Gobel). Skripsi. Depok: Departemen Geografi FMIPA UI.

Watson, D. F., and G. M. Philip. 1985. A Refinement of Inverse Distance Weighted Interpolation. Geo-processing, 2: 315-327.

Witono, D. 2003. Karakteristik Pencemaran Udara di PLTGU UJB-I Tambak Lorok Semarang (Studi Kasus Pencemaran SO2 dan Partikel Debu). Tesis. Jakarta: Program Studi IImu Lingkungan UNDIP.

Wyrtki, K. 1961. Physical Oceanography of the Southeast Asian Waters. Scripps Institution of Oceanography, The University of California, La Jolla. 